\title{
Mesoscale distribution and population dynamics of Rhincalanus gigas and Calanus simillimus in the Antarctic Polar Open Ocean and Polar Frontal Zone during summer
}

\author{
P. Ward*, R. S. Shreeve, G. C. Cripps, P. N. Trathan \\ British Antarctic Survey, Natural Environment Research Council, High Cross, Madingley Road, Cambridge CB3 0ET, \\ United Kingdom
}

\begin{abstract}
Two dominant Antarctic copepod species, Rhincalanus gigas and Calanus simillimus, were sampled at stations along a $420 \mathrm{~km}$ transect running from Maurice Ewing Bank $\left(50^{\circ} \mathrm{S}, 42^{\circ} \mathrm{W}\right)$ towards South Georgla $\left(54^{\circ} \mathrm{S}, 37.5^{\circ} \mathrm{W}\right)$ during early January 1994 and again 1 mo later. The transect spanned the Polar Frontal Zone (PFZ), crossing the Polar Front (PF) into Antarctic surface waters. In January, diatom blooms were present immediately south of the PF and at open ocean stations further south where unusually high total pigment levels up to $800 \mathrm{mg} \mathrm{m}^{-2}$ were recorded. In early January, north of the PF. R. gigas had not yet commenced spawning although recruitment had begun to the south. I:arly stages of $C$. simillimus copepodites were, however, present at all stations sampled. South of the PF both gonad maturity and lipid levels in $R$. gigas showed a clear positive relationship with the elevated pigment concentrations. C. simillimus females, on the other hand, were ripe at the majority of stations sampled regardless of pigment levels. A month later postbloom conditions were present over the greater part of the transect and the summer generation of both species was present at all stations. A proportion of the summer generation of $C$. simillimus had already reached adulthood and their gonads were maturing. The populations of both species were older in PFZ waters, and mean population age showed a strong correlation with water temperature. Prosome length of stages CIV, CV and CVIo $R$. gigas was negatively correlated with sea surface temperature. This was not the case for $C$. simillimus females, suggesting that they had been recruited earlier in the season under different environmental conditions. Lipid analysis indicated that $R$. gigas predominantly stored wax esters, in contrast to $C$. simillimus where the dominant lipid class was triacylgycerol. These observations coupled with literature data on feeding and seasonal vertical distribution seem to indicate fundamently different life history patterns.
\end{abstract}

KEY WORDS: Copepoda Population dynamics Polar frontal zone Lipid Southern Ocean

\section{INTRODUCTION}

Biogeographic studies of plankton distributions have repeatedly demonstrated that there are strong associations between water masses and zooplankton communities (Haury et al. 1978). At the mesoscale (10s of km), differences in abundance are commonly observed, whereas at larger scales (100s of $\mathrm{km}$ ) differences in species composition are often seen (Piatkowski 1989, Atkinson et al. 1990, Tarling et al. 1995). Variations in

•E-mail: pwar@pcmal.nerc-bas.ac.uk population stage structure, development rates and physiological condition can also occur at the mesoscale, both within a water mass (e.g. neritic/oceanic differences, Boysen-Ennen \& Piatkowski 1988, Huntley \& Brinton 1991, Huntley \& Escritor 1991) and across fronts separating water masses where differences in temperature and food supply may be influential (e.g Marin 1987. Piatkowski 1989). Specifically within the Antarctic, Atkinson (1991) has demonstrated the widespread distributions, yet differing proportions, of commonly occurring large copepods in water masses ranging from the sub-Antarctic to the Weddell Sea. 
Relatively few mesoscale plankton studies in the Southern Ocean encompass the more northerly regions including the Polar Front (PF) and Polar Frontal Zone (PFZ). Mackintosh (1934) and Voronina (1978) have found that whilst some epipelagic plankters were as abundant on one side of the PF as the other, for others it represented a distinct faunistic boundary. Mackintosh (1937) also illustrated the seasonal distribution of the plankton along $80^{\circ} \mathrm{W}$ from $55^{\circ} \mathrm{S}$ as far south as $70^{\circ} \mathrm{S}$. Changes in the horizontal extent of the plankton along this meridian were clearly linked to seasonal changes in its vertical distribution.

In this paper we concentrate on the distribution and population biology of the 2 dominant species of copepods, in terms of biomass, in this region, Rhincalanus gigas and Calanus simillimus. Both species occur widely in the AAZ (Antarctic Zone), across the PFZ, and into sub-Antarctic waters. $R$. gigas is an Antarctic form that during summer, at least, is present in surface waters on both sides of the PF (Ommanney 1936, Mackintosh 1937, Voronina 1970). C. simillimus on the other hand has a sub-Antarctic distribution although it is capable of extending its range southwards into the Antarctic (Vervoort 1965, Marin 1987). Both species are spring/summer spawners and are generally thought to have a 1 yr life-cycle.

Sampling took place at stations along a transect running from Maurice Ewing Bank (MEB) $150^{\circ} \mathrm{S}$, $\left.42^{\circ} \mathrm{W}\right)$ to South Georgia $\left(54^{\circ} \mathrm{S}, 37.5^{\circ} \mathrm{W}\right)$ which encompassed PFZ water in the north, the PF, and surface waters of the AAZ. The transect was sampled twice, comprising 8 stations in early January (T1) and again 4 wk later in early February when sampling was undertaken at 14 stations (T2). Each traverse was completed in $\sim 50$ to $60 \mathrm{~h}$. The objectives of the study were to use these quasi-synoptic observations to investigate differences in population biology of the 2 copepod species, and to investigate their responses to changing environmental conditions both within and between different water masses. Two additional stations, one on the shelf near the Willis Islands, South Georgia, in proximity to the southern end of the transect (sampled from 10 to $18 \mathrm{Jan}$ ), and the other near to the PF (sampled from 4 to 12 Feb), enabled a further examination of lipid biochemistry and egg production rates.

\section{METHODS}

The position of the transect and sampling stations are given in Fig. 1. Temperature and salinity data were monitored from the ship's $6 \mathrm{~m}$ nontoxic seawater supply using a Sea-Bird Electronics ${ }^{R}$ thermosalinograph. A Turner designs ${ }^{R}$ fluorometer was used to measure

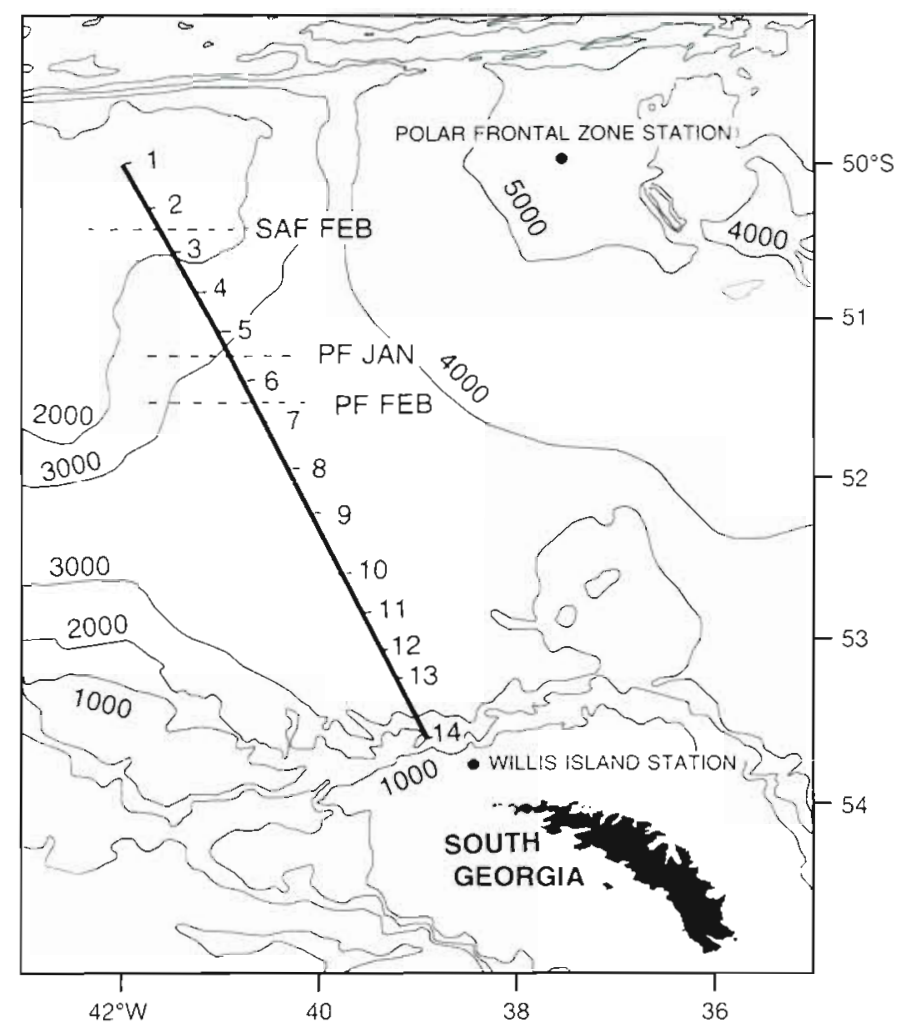

Fig. 1. The study area. Transect Stns 1 to 3 and 6 to 10 were sampled during January and Stns 1 to 14 during February. The positions of the Polar Front in January (PF JAN) and February (PF FEB) and sub-Antarctic Front during Febrary (SAF FEB) are given as well as the location of the Willis Islands and Polar Frontal Zone stations

fluorescence. On both traverses a CTD rosette was deployed at each station to at least $1000 \mathrm{~m}$ and water bottle profiles were taken for chlorophyll and nutrient analyses.

Zooplankton were sampled using an $0.75 \mathrm{~m}$ diameter ring net with a $5 \mathrm{l}$ solid cod end that was deployed to $200 \mathrm{~m}$ and slowly hauled to the surface at $\sim 0.15 \mathrm{~m} \mathrm{~s}^{-1}$. Owing to logistic constraints zooplankton were only sampled at 8 of the 14 stations on T1 (starting at the northern end, Stns 1 to 3 and 6 to 10). As a result of bloom conditions encountered at stations on the southern end of the transect during T1 different net mesh sizes were used. Stations north of the PF (1 to 3) and $\operatorname{Stn} 6$ were sampled with a $200 \mu \mathrm{m}$ net. When this was found to be clogging (Stns 7 to 10) a $500 \mu \mathrm{m}$ net was substituted and, in addition, a $100 \mu \mathrm{m}$ net was also fished at these stations. During T2 the postbloom conditions allowed the use of a $200 \mu \mathrm{m}$ net at all 14 stations.

All copepodite stages of the 2 species were enumerated from each of the nets. Mean stage estimates were restricted to the $100 \mu \mathrm{m}$ and $200 \mu \mathrm{m}$ samples which represented the abundance of the younger stages 
more accurately. The mean population stage $(S)$ was calculated according to

$$
(S)=\frac{n \mathrm{CI}+2 n \mathrm{CII}+\ldots+6 n \mathrm{CVI}}{N}
$$

where $n \mathrm{CI}, 2 n \mathrm{CII}, \ldots$, are the number of respective stages and $\mathrm{N}$ the total number counted.

Where possible 30 females of both species were removed from each sample and the prosome length measured. Gonad maturity was also assessed using criteria defined by Ward \& Shreeve (1995), with the single exception that the mature stage was subdivided into early and late categories. In the case of Rhincalanus gigas the lipid sac was measured and its volume obtained by approximation to a cylinder. Prosome length and lipid sac volume was also determined for $30 \mathrm{CIV}$ and CV R. gigas from each station sampled on both traverses. Stages were examined under a binocular microscope equipped with an eyepiece graticule.

At the Willis Island and PF stations samples were obtained using the same nets and were analysed in an identical fashion. Egg production experiments were carried out on Rhincalanus gigas (both stations) and on Calanus simillimus (PF station only) by randomly removing undamaged females from the codend samples and transferring them, either individually or in groups of 5 , to perspex inserts with an $800 \mu \mathrm{m}$ mesh bottom suspended in $1.5 \mathrm{l}$ jars of filtered seawater. Jars were incubated in the dark at ambient surface seawater temperature for $24 \mathrm{~h}$. At the end of the incubation period the contents of the jars were filtered through a $53 \mu \mathrm{m}$ screen, resuspended in a petri dish and eggs counted under a microscope. Aliquots of some of the catches were also filtered onto squares of $200 \mu \mathrm{m}$ mesh and immediately frozen at $-60^{\circ} \mathrm{C}$. In the United Kingdom these samples were quickly and carefully thawed out in sea water at an ambient temperature of $2^{\circ} \mathrm{C}$ and sorted into species stages. Batches of 15 to 100 individuals were then extracted in chloroform/methanol (2:1 v:v). Samples were homogenised and separated according to Folch et al. (1957) and the extracted lipid dried to constant weight in a stream of nitrogen. Sam- ples were then resuspended in chloroform/methanol and applied to HPTLC plates so as to give a loading of $\sim 15 \mu \mathrm{g}$ per analysis and run as single developments following the method of Olsen \& Henderson (1989). Wax ester rich and triacylglycerol rich lipid standards were prepared according to Hagen (1988).

Dry masses of copepods were obtained from replicate batches of species stages which were sorted from the frozen material and dried to constant mass at $60^{\circ} \mathrm{C}$. At the shelf station near South Georgia insufficient frozen material was available for dry mass determinations of Calanus simillimus females. Dry mass was therefore estimated by comparing formalin preserved dry mass determinations from the PFZ station with those made on fresh/frozen material. The proportional difference between the two was then applied to the formalin preserved estimate from the Willis Island station and a fresh/frozen dry mass estimate derived.

\section{RESULTS}

\section{Environment}

Sea surface temperature and total integrated phytopigment (chlorophyll a and phaeopigment 0 to $100 \mathrm{~m}$ ) along the transect are shown in Fig. 2. On T1 the PF was located between Stns 5 and 6 with sea surface temperatures dropping from $5-6^{\circ} \mathrm{C}$ at the first few stations to approximately $3^{\circ} \mathrm{C}$ on the southern side of the front.

Total plant pigment was relatively low to the north of the front, averaging $\sim 100 \mathrm{mg} \mathrm{m}^{-2}$. Values were higher at Stn 6 immediately to the south of the front and surface data also indicated a bloom coincident with this feature. Levels fell and then increased dramatically towards South Georgia, approaching $800 \mathrm{mg} \mathrm{m}^{-2}$. On T2, sea surface temperatures were approximately 1 to $1.5^{\circ} \mathrm{C}$ higher throughout the transect, probably due to summer warming The surface expression of the PF, indicated on the thermosalinograph, was encountered slightly further south and the 2 most northerly stations were outside the $\mathrm{PFZ}$, lying in sub-Antarctic water
A. January

Fig. 2. Total pigment (phaeopigment and chlorophyll a) $\mathrm{mg}$ $\mathrm{m}^{-2}(0$ to $100 \mathrm{~m})$ and sea surface temperature $\left({ }^{\circ} \mathrm{C}\right)$ in $(\mathrm{A})$ January and (B) February. Filled portion of bar: phaeopigment; open portion: chlorophyll a. Note change in pigment scale between January and February. SAF: position of sub-Antarctic Front; PF: position of Polar Front

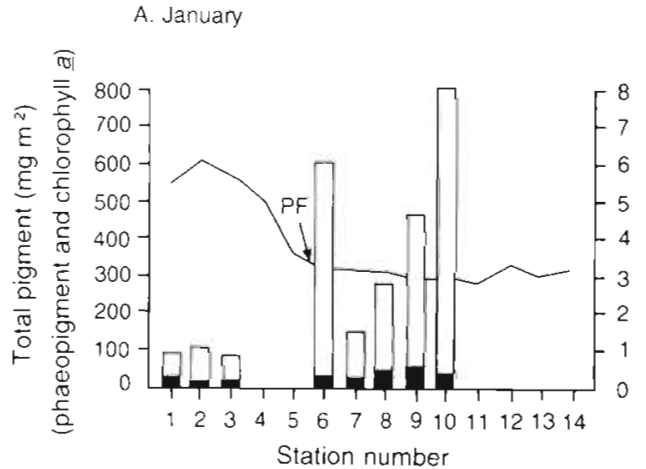

B February

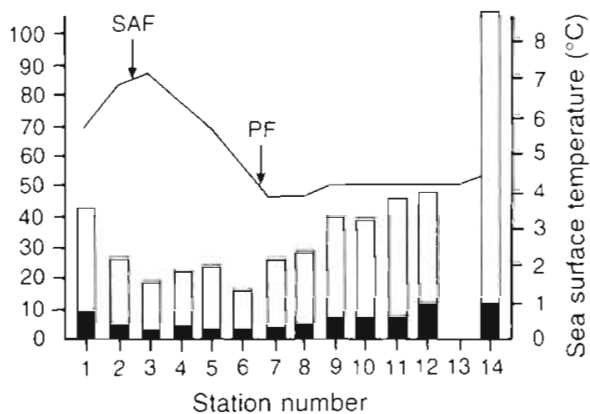


Pigment levels were still higher at stations closer to South Georgia but fell sharply to low post bloom levels over the rest of the transect. Plots of the proportion of phaeopigment in relation to total pigment are shown in Fig. 2. On T1, stations north of the PF had relatively higher amounts of phaeopigment (15 to $30 \%$ ). South of the PF the proportion fell in relation to greatly increased levels of total pigment. This, and the fact that with the exception of Stns 5 and 6, where high pigment levels were associated with the PF, suggests that in passing from north to south along the transect a transition from postbloom to full bloom conclitions took place. On T2 the proportion of phaeopigment showed no discernable pattern with respect to station order although the proportion showed a general increase with increasing total pigment.

P. N. Trathan, M. A. Brandon \& E. J. Murphy (unpubl.) have shown that during the occupation of the transect geostrophic flows indicated variability in water speed and direction. On both traverses stations over the southern edge of MEB lay in a narrow $(100 \mathrm{~km})$ high speed band of northeastward flowing water corresponding to the PF. Maximum flow of this band was up to $17 \mathrm{~cm} \mathrm{~s}^{-1}$ on T1 and $12 \mathrm{~cm} \mathrm{~s}^{-1}$ on T2 (200 dbar referenced to a level of no motion at $1000 \mathrm{dbar}$ ). In other areas of the transect, flows were lower and in some cases moved in a southwesterly direction counter to the main direction of the Anarctic Circumpolar Current $(\mathrm{ACC}$ ) (Trathan et al. unpubl.).

\section{Population stage structure}

Rhincalanus gigas. Stage frequency distributions for T1 were notable for the almost complete absence of copepodite stages $\mathrm{CI}$ to CIII north of the PF (Fig. 3) Older stages were largely CVs and adults indicating that in this part of its range this species was only just
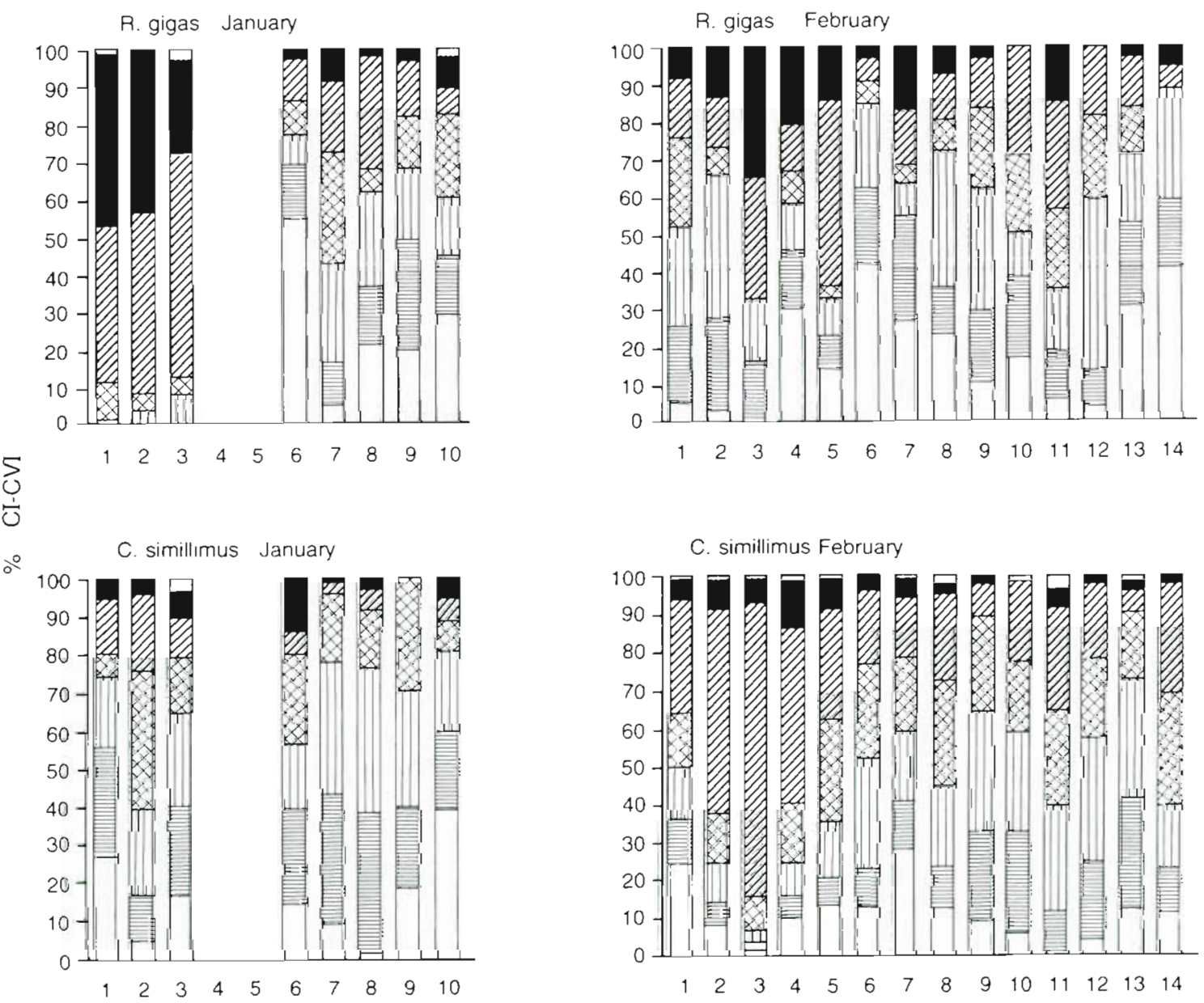

Station number

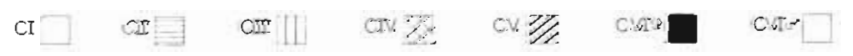

Station number

Fig. 3. Rhincalanus gigas and Calanus simillimus. Stage frequency distributions in January and in February 
beginning to spawn. South of the PF younger stages were present in variable proportion, outnumbering older stages at the majority of stations. The presence of the overwintered and summer generations at these stations was reflected by the bimodal distributions. On T1 there was a clear decline in mean age from stations north of the PF to those closer to South Georgia (Fig. 4). On T2 younger copepodite stages were present at ali 14 stations. Bimodality was less obvious with a single mode being the norm skewed either to younger or older stages. At Stns 1 to 3 on T2 the mean population age was younger than on $\mathrm{T} 1$, a possible result of recruitment having taken place in the interim month. South of the PF mean age was variable, the population being older at Stns 6, 9 and 10 and younger at Stns 7 and 8 . The north to south decrease in mean age, however, was still apparent.

Calanus simillimus. In this species the summer generation, stages CI to CIII, was dominant on both sides of the PF on T1 and there was no evidence of bimodality. By T2 there was an increase in the proportion of older stages throughout the transect particularly north of the PF and a corresponding increase in the mean population age (up to 1.75 stages) at those stations commonly sampled on both traverses.

\section{Gonad condition}

Rhincalanus gigas. With the exception of stations north of the PF, female gonad maturity demonstrated a positive relationship with total pigment on T1 (Pearson Corr. $=0.904)$. At Stns 1 and 2 the majority of fernales were approaching maturity whereas at Stns 3 and 7 they were clearly immature (Fig. 5). At maximum pigment concentrations (Stns 6,9 and 10) the majority were fully mature and a proportion ripe. On T2 stations north of the PF were broadly at the same level of maturity as seen on T1 although the proportion of ripe females had increased. At Stns 8 to 12 there was an increasing proportion of immature females despite slight increases in total pigment.

Calanus simillimus. In contrast, 80 to $100 \%$ of C. simillimus females were ripe at every station sampled on $\mathrm{T} 1$. A month later, although the number of ripe females was still high, increased proportions of earlier maturity stages were seen at most stations particularly north of the PF.

\section{Willis Island station}

Water at this station was essentially of AAZ origin with a surface temperature of $\sim 3^{\circ} \mathrm{C}$. Chlorophyll a concentrations were initially high [up to $>1000 \mathrm{mg} \mathrm{m}^{-2}$ $(0$ to $100 \mathrm{~m})]$ with $>90 \%$ of the biomass in the $>20 \mu \mathrm{m}$ fraction which was dominated by large colonial diatoms. Levels declined to $-500 \mathrm{mg} \mathrm{m}^{-2}$ during our occupation of the station

Rhincalanus gigas. Of the females, $80 \%$ were mature or ripe and eggs were being produced. Egg production experiments indicated 60 to $70 \%$ of females spawning and maximum egg production rates
Fig. 4. (A, B) Rhincalanus gigas and (C, D) Calanus simillimus. Mean population stage vs station and sea surface temperature $\left({ }^{\circ} \mathrm{C}\right)$. (0) data for January; (₫) February
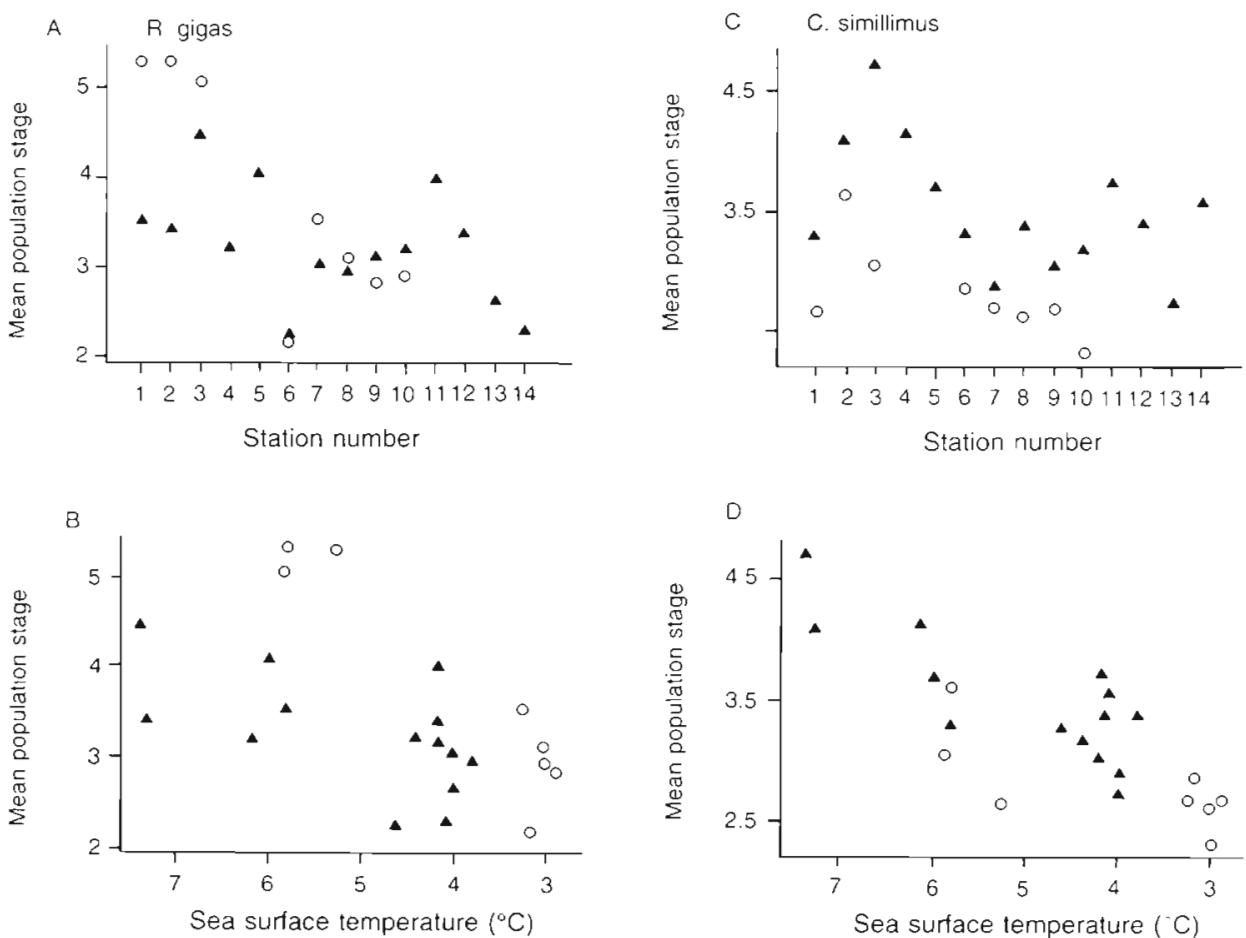

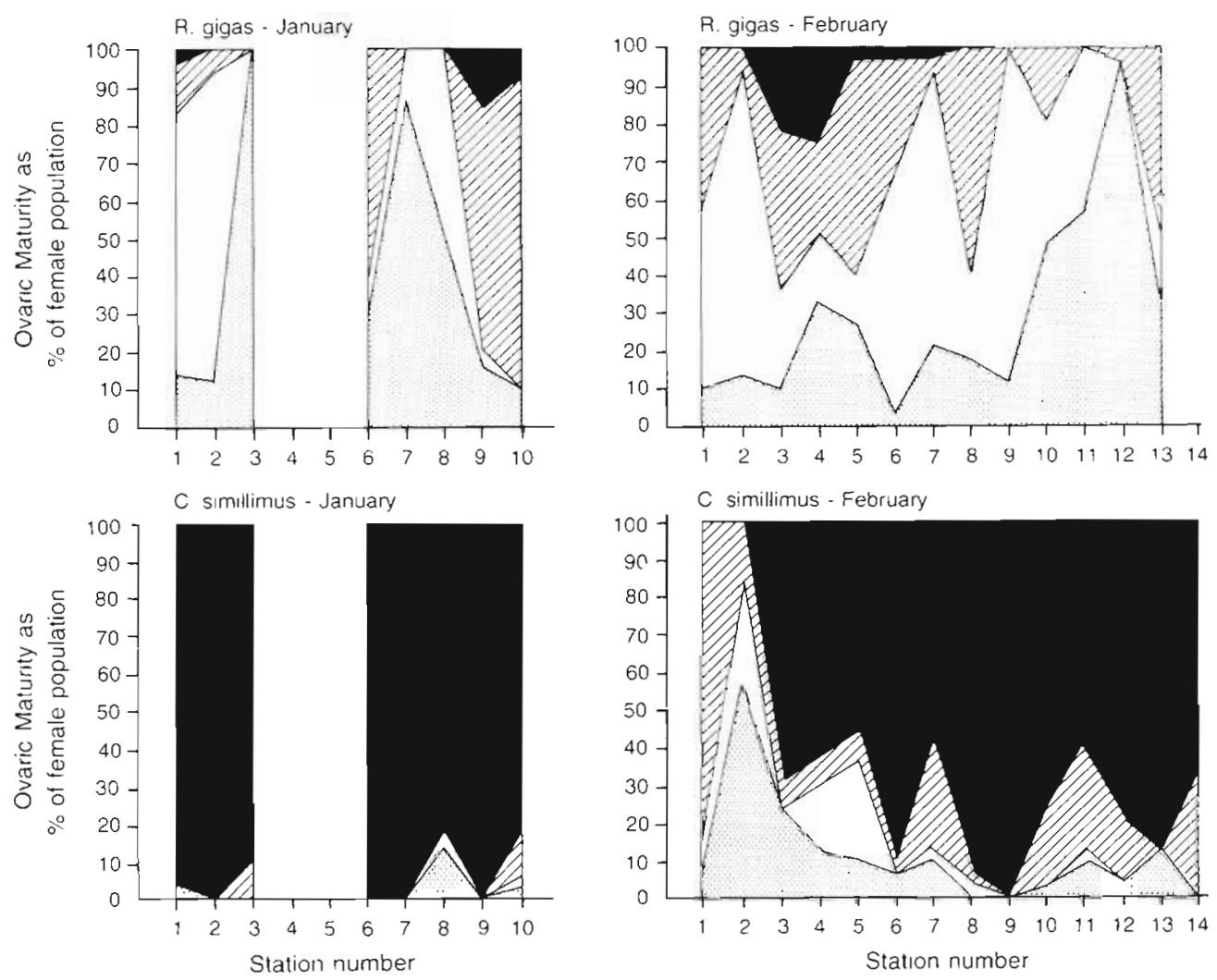

Fig. 5. Rhincalanus gigas and Calanus simillimus. Ovaric maturity as a percentage of the female population in January and in February. Stippled area: immature; open area: early mature; hatched area: late mature; solid area: ripe

of 23 eggs female ${ }^{-1} \mathrm{~d}^{-1}$ The mean age of the population was 3.4 (range 3.2 to 4.0 ). Dry mass of females and CIVs and CVs was high (Table 1).

Calanus simillimus. Of the females, $94 \%$ were either mature or ripe. Although insufficient females could be found in samples with which to carry out egg production experiments (largely due to problems in sorting material in the dense bloom samples), analysis of formalin preserved samples indicated the presence of early copepodites
Polar Front Zone station

In this region there was substantial mesoscale variability and the station was based near the centre of a warm core ring (Trathan et al. unpubl.). Surface temperature was 5 to $6^{\circ} \mathrm{C}$ and phytoplankton biomass was low $\left(50 \mathrm{mg} \mathrm{m}^{-2}\right.$ ). In contrast to the Willis Island station the majority of the pigment was $<20 \mu \mathrm{m}$, small diatoms were scarce but small dinoflagellates and cryptomonads were abundant.

Table 1. Rhincalanus gigas and Calanus simillimus. Dry mass and lipid data from the Willis Islands and Polar Frontal Zone stations. Data are means \pm SD. (n): no. of replicates of between 30 and 50 individuals

\begin{tabular}{|c|c|c|c|c|c|}
\hline & \multicolumn{2}{|c|}{ Rhincalanus gigas } & \multicolumn{3}{|c|}{ Calanus simillimus } \\
\hline & $\mathrm{CV}$ & CVIọ & $\mathrm{CV}$ & CVIo (imm.) & CVIo (ripe) \\
\hline \multicolumn{6}{|l|}{ Willis Island station } \\
\hline Body dry mass $(\mu \mathrm{g})$ & $2043 \pm 487$ (5) & $3004 \pm 564(11)$ & $137^{\circ}$ & $305^{a}$ & $295^{\mathrm{a}}$ \\
\hline Total lipid ( $\mu g)$ & $326 \pm 81(3)$ & $851 \pm 234$ & $42 \pm 8(3)$ & $58(1)$ & $32(1)$ \\
\hline Wax ester $(\mu \mathrm{g})$ & $215 \pm 75(3)$ & $515 \pm 214$ & $1.8 \pm 0.8(3)$ & $5.8(1)$ & $4.4(1)$ \\
\hline Triacylglycerol ( $\mu \mathrm{g})$ & $49 \pm 13(3)$ & $125 \pm 38(5)$ & $23 \pm 13(3)$ & $27.1(1)$ & $14.3(1)$ \\
\hline \multicolumn{6}{|c|}{ Polar Frontal Zone station } \\
\hline Body dry mass ( $\mu g)$ & $772 \pm 177(4)$ & $1085 \pm 117(3)$ & $185 \pm 41(16)$ & $329 \pm 27(4)$ & $320(1)$ \\
\hline Total lipid $(\mu \mathrm{g})$ & $151 \pm 0.7(2)$ & $115 \pm 2(2)$ & $72 \pm 20$ & $85=36(2)$ & $32 \pm 1.7\{2\}$ \\
\hline Wax ester ( $\mu g$ ) & $87 \pm 6(2)$ & $80 \pm 14(2)$ & $0.2 \pm 0.2(5)$ & $0.4 \pm 0.4(2)$ & $0.6 \pm 0.4(2)$ \\
\hline Triacylglycerol $(\mu g)$ & $6 \pm 4(2)$ & $1.5 \pm 2(2)$ & $45 \pm 10(5)$ & $73 \pm 34(2)$ & $19 \pm 4(2)$ \\
\hline
\end{tabular}


Rhincalanus gigas. In marked contrast to the Willis Island station worked some 3 wk earlier the majority of females were immature (68\%) and none were ripe. No eggs were produced by the females that were incubated. The mean population stage was approximately the same as at the South Georgia station (3.4). Dry masses of females and stages CIV and CV were some 5 times lower than at the South Georgia station and oil sac volumes were 8 times less.

Calanus simillimus. The mean population stage at this station was 4.3, older than at Willis Island but comparable to stations worked near the PF during T2. Approximately equal proportions of the female population were immature $(39 \%)$ or ripe $(42 \%)$. Egg production experiments indicated that 40 to $50 \%$ of the population was spawning and maximum egg production was 6 eggs female ${ }^{-1} \mathrm{~d}^{-1}$.

\section{Lipid}

Rhincalanus gigas. On T1 there was a strong relationship between total pigment and lipid sac volume in CVs and adults (Fig. 6). As with total pigment, south of the PF, lipid sac volume increased with increasing proximity to South Georgia, the exception being Stn 6 which was located in a bloom associated with the PF. Lipid sac volumes at the first 3 stations were only 20 to $30 \%$ of those at the southern end of the transect. The relationship with total pigment is clearly asymptotic and probably reflects the fact that females at Stns 6,9 and 10 had accumulated the maximum amount of oil they were capable of. One month later on T2, females north of the PF had increased amounts of lipid compared to on $\mathrm{T} 1$ but at the 5 stations south of the PF, females contained approximately half the volume of oil observed on T1 There was only a weak positive relationship between total pigment and lipid volume at this time which may indicate that, to an extent, lipid content is less in equilibrium with available food and reflects more the higher levels of food available on T1

Similar relationships between food and lipid content between traverses were observed for stages CIV and
CV. At stations north of the PF lipid content of CVs exceeded that of females.

Our data on lipid amounts and class composition are reported more fully elsewhere (Ward et al. in press) and we only summarize those findings here. Lipid content of CV and female Rhincalanus gigas and Calanus simillimus is given in Table 1

At the Willis Island station Rhincalanus gigas was approximately 3 times as heavy as at the PFZ station and lipid content was some 7.5 times greater This amount of lipid was consistent with our measured volumes (mean 8 times higher). Lipid class composition (Table 1) indicated that at both stations the dominant component for $R$. gigas was wax esters $160 \%$ and $70 \%$ respectively)

Calanus simillimus. Female $C$. simillimus were distinguished according to whether they were immature or ripe. The former grouping had variable amounts of oil present and the standard deviation of the mean amount of lipid extracted at the PFZ station was high. Dry mass determinations indicated immature females to be slightly heavier at the PFZ station. The amount of lipid extracted from ripe females was $-10 \%$ of dry mass at both stations, whereas amounts from immature females were higher at both stations $17 \%$ at the Willis Island station and $25 \%$ at the PFZ station.

The major lipid component in this species was triacylglycerol with higher amounts being found in immature females, particularly at the PFZ station. Wax ester was present in moderate amounts in females at the Willis Island station but amounted to $<2 \%$ at the PFZ station

\section{DISCUSSION}

The PF is an area of convergence of varying strength. At some locations the exchange of water and zooplankton across this feature is extremely restricted although at others mixed faunal zones may extend for several hundred miles (Voronina 1978, Tarling et al. 1995). In the Atlantic sector of the Southern Ocean the $\mathrm{PF}$ is extremely dynamic with the generation of intense
Fig. 6. Rhincalanus gigas. Lipid volume $\left(\mathrm{mm}^{3}\right)$ vs total pigment ( $\mathrm{mg} \mathrm{m} \mathrm{m}^{-2}$ 0 to $100 \mathrm{~m}$ ) in January and in February. (-.-) CVlo: (-) CV; $(\ldots .$.$) CIV$
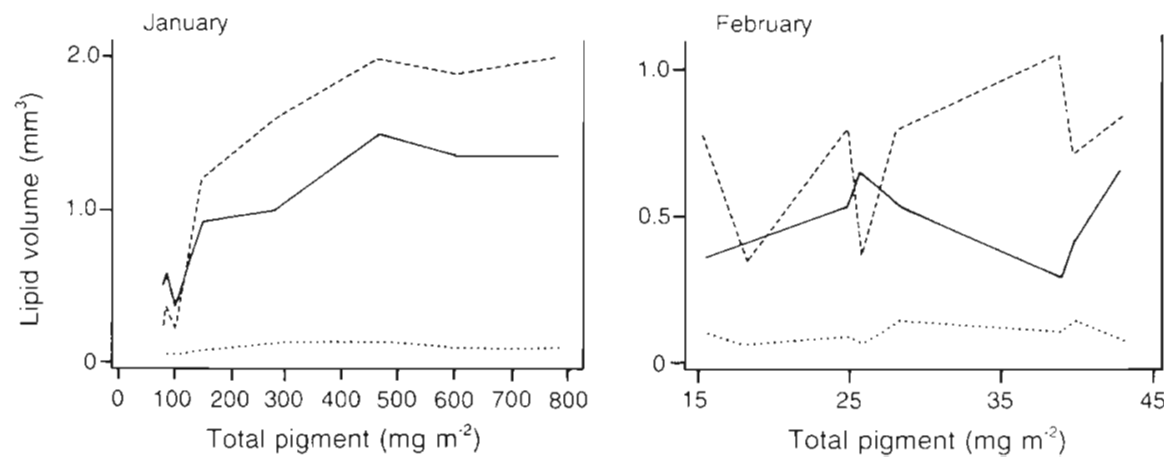
eddies and the propogation of meanders and core rings being commonplace (Gordon et al. 1977, Legeckis 1977. Hofmann \& Whitworth 1985, Priddle et al. 1988, Atkinson et al. 1990). In the PFZ there is often a widespread distribution of zooplankton species that are also common in the AAZ, e.g. Euphausia triacantha (Baker 1959). Eukrohnia hamata (Mackintosh 1937) and the 2 copepods that form the focus of this study.

From an extensive seasonal analysis of 'Discovery' material, Atkinson (1991) concluded that of the 2 species being considered here Calanus simillimus has the more northerly distribution in the Atlantic sector being particularly abundant in the sub-Antarctic zone, a view which is in accord with that of Vervoort (1965). The southern limit of its distribution would appear to be the southern part of the Scotia Sea (Mackintosh 1934, Marin 1987, Atkinson 1991). Although Rhincalanus gigas was present in water types ranging from the sub-Antarctic to the Weddell Sca (Atkinson 1991) it was most abundant north of the PF. Ommanney (1936), plotting spring and summer distributions of $R$. gigas in the same region, noted some interannual variation with maxima extending into the Antarctic zone during some years and suggested that the $5^{\circ} \mathrm{C}$ surface isotherm marked its northern boundary. It is present in the Weddell Sea in greatly reduced abundance $1 \mathrm{Om}$ manney 1936, Bathmann et al. 1993). Both species are therefore essentially inhabitants of the ice-free zone.

To be able to link our observations on these 2 species sampled 1 mo apart, we firstly need to consider the general oceanographic environment of the study area. South Georgia lies north of the seasonal ice zone in the predominantly eastwards flowing $A A Z$, in the Permanently Open Ocean Zone (POOZ; Tréguer \& Jacques 1992). The transect extended in a northwesterly direction to Maurice Ewing Bank passing over the PF and into the PFZ. To the west of the transect a major topographically induced deflection occurs in the ACC where it passes through the Scotia Arc. Movements in the position of the PF of up to $100 \mathrm{~km}$ on time scales as little as $10 \mathrm{~d}$ have been recorded in this vicinity (e.g. Nowlin \& Klinck 1986), as has the generation of eddies and meanders. The region is thus hydrographically complex and an important determinant of current flow and direction is bathymetry. Measurements of geostrophic flow taken along the transect during both months (Fig. 7) were in good agreement with those predicted by the Fine Resolution Antarctic Model (FRAM Group 1991) (see Trathan et al. unpubl.). The level 7 (185 to $245 \mathrm{~m}$ depth range) current vectors from this model predicts the high velocity flow found along the southern edge of MEB, as well as the relatively slow flow found in the middle of the transect and the westward movement immediately north of South Georgia. Strong eastward flows in the ACC have also been described in this region by Davis et al. (1996) who compared FRAM data with drifter trajectories, whilst the westward flow along the north of South Georgia has been suggested by Hardy \& Gunther (1935), Deacon (1937) and more recently Whitworth et al. (1991). Thus although the animals found at all stations along the transect likely originate well to the south and west, variable current regimes will affect stations differently. For example, animals in the vicinity of the PF sampled
(A)

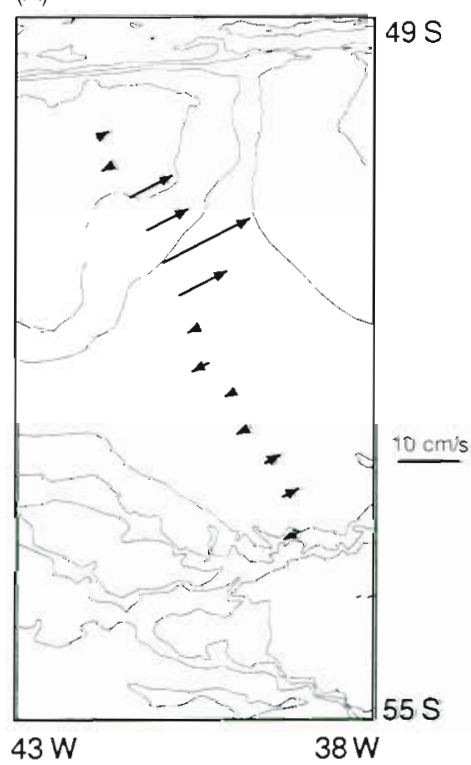

(B)

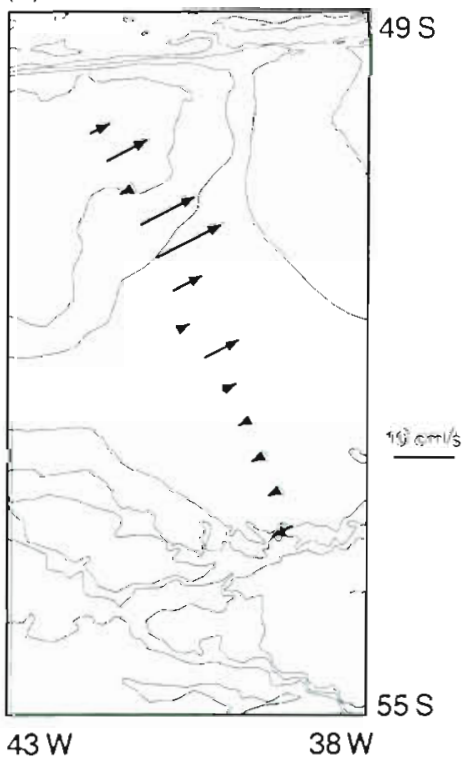

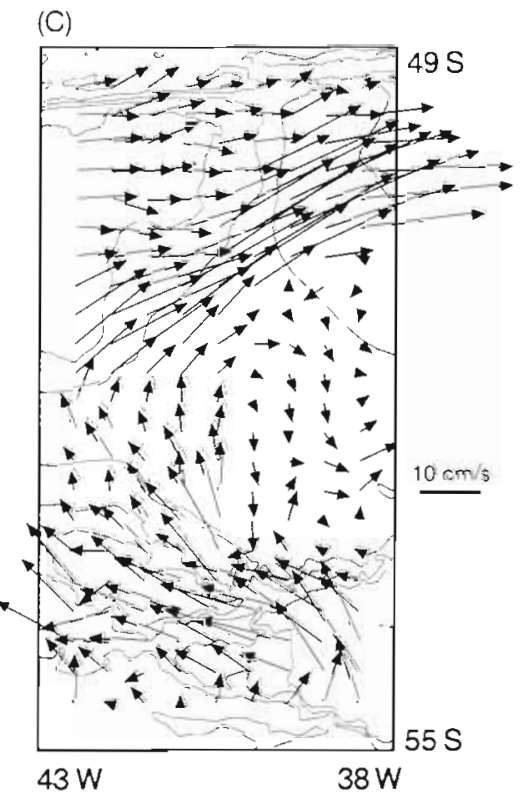

Fig. 7. Geostrophic flow at $200 \mathrm{~m}$ along the transect in (A) January and (B) February. (C) Output from the Fine Resolution Antarctic Model (FRAM) level 7 (185 to $245 \mathrm{~m}$ ) for the same area 
on $\mathrm{T} 1$ would, at their recorded speed, be $500 \mathrm{~km}$ away 1 mo later; whereas those along the middle of the transect may to an extent be retained in the area of low and variable flow. Despite the dynamic nature of the study area no mesoscale features or rapid movement of fronts were detected along the transect on either occasion. However, a single satellite image obtained during January indicated eddy-like structures $<100 \mathrm{~km}$ wide and $1^{\circ} \mathrm{C}$ warmer than surrounding water at approximately $45^{\circ} \mathrm{W}$ (Whitehouse et al. 1996).

However, clear evidence exists that on $\mathrm{T} 2$ a different population of animals was sampled. Examination of the mean prosome length of Rhincalanus gigas showed a clear negative relationship with sea surface temperature during both traverses (Fig. 8). At the majority of stations, stages were generally smaller on T2 compared to on T1 strongly suggesting that seasonal warming and/or food availability had influenced development rates (sensu Vidal 1980) and hence body length. Only on T2 was a similar length/temperature relationship seen for female Calanus simillimus, and on both traverses scatter of data was high. Rather than pointing to a different origin (both species are present in surface water masses at this time of year) it perhaps

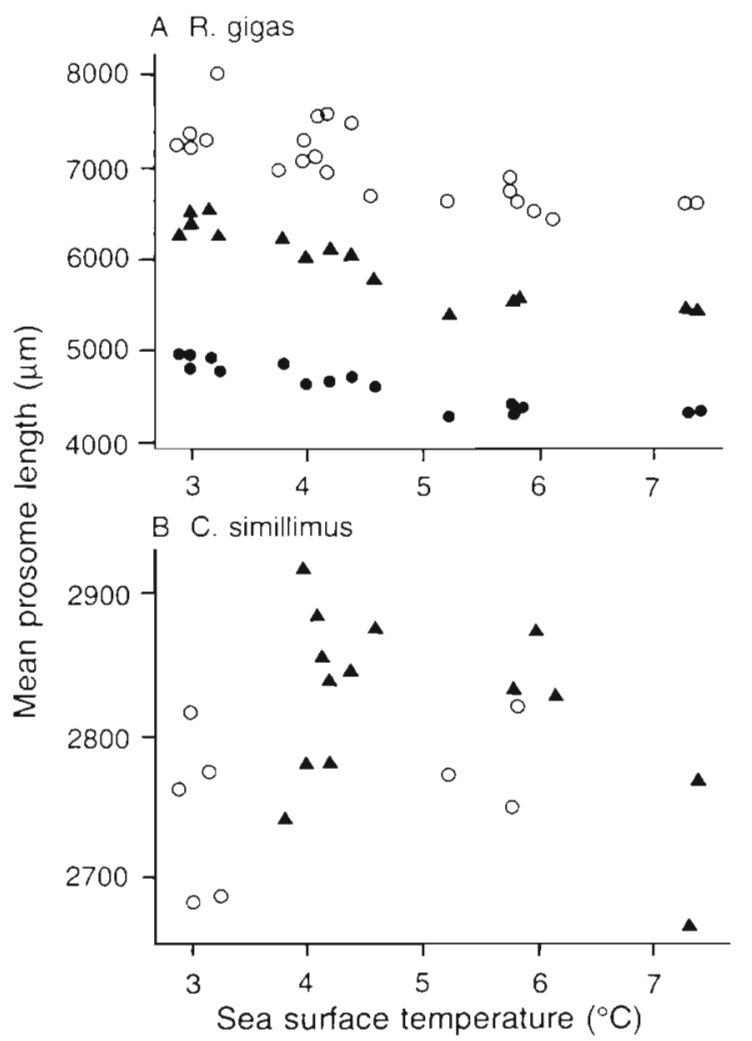

Fig. 8. (A) Rhincalanus gigas and (B) Calanus simillimus. Mean prosome length $(\mu \mathrm{m})$ vs sea surface temperature $\left({ }^{\circ} \mathrm{C}\right)$. Data for $R$. gigas are pooled transect data from January and February: (0) CVIq, (4) CV, (•) CIV. For C. simillimus: (O) data for January, (₫) February indicates that the $C$. simillimus female population was older, and in terms of growth, affected by factors occurring before sampling on $\mathrm{T} 1$. This is also consistent with the view that in our study area spawning of $R$. gigas commences in December (Ommanney 1936, Atkinson 1989). Spawning in C. simillimus has been reported in November at $\sim 55^{\circ} \mathrm{S}$ although mature individuals were found in surface waters as early as August north of the PF (Voronina et al. 1978).

Relationships between temperature/latitude and mean population stage for both species indicate an older population at the more northerly stations on both traverses (Fig. 4). On T1 in the case of Rhincalanus gigas this is due to reproduction not yet having commenced north of the PF, an effect still apparent 1 mo later. This is broadly in agreement with Ommanney (1936) who suggested a later start and a less intense recruitment in PFZ waters. However, he and other authors (e.g. Kanaeva 1968, Marin 1987) have also noted other regional variations in the timing of recruitment broadly linked to differences in water temperature, with spawning taking place earlier in warmer Antarctic waters. Thus $R$ gigas does not appear to adhere to this pattern north of the PF and here may be at its northern limit for succesful reproduction.

Recruitment of Calanus simillimus had already commenced along the entire length of the transect by the start of January. This species appears to start spawning in spring, the new generation becoming abundant by December (Atkinson 1991). Evidence suggests that spawning is retarded in the colder part of its range which may in turn account for the temperature/latitudinal differences in mean age seen along the transect in both months. Reproduction may have been delayed at the southern end of the transect and/or higher temperatures further north may have increased development rates. Although the mean population age of $C$. simillimus had increased by the largest increment (1.75 stages) at $\operatorname{Stn} 3$ at the warmer end of the transect, Stns 1 and 2 showed progression in the range seen at those stations south of the PF. Thus a clear temperature effect was not demonstrated. On T2 the proportion of ripe females was generally less than 1 mo previously. The increased proportions of immature and early maturing females, particularly north of the PF, may represent newly moulted CVs from the summer generation which may in turn spawn in the autumn. The mean stage of the population was older at those stations commonly sampled on both traverses during T2.

One clear response of the Rhincalanus gigas population to the bloom conditions experienced on T1 was to increase amounts of stored lipid. Literature data suggest that the annual primary production cycle in the POOZ is unimodal (Hart 1942). Although Tréguer \& Jacques (1992), reviewing studies made in the Indian 
Ocean sector, concluded that in these oligotrophic waters where turbulent mixing is a governing factor on phytoplankton growth, blooms $\left(>1.5 \mathrm{mg} \mathrm{m}^{-3}\right.$ chlorophyll a) rarely occurred. In this study, the northernmost bloom appeared to be associated with the PF jet. The origin of the bloom at the southern stations on the transect is, however, unclear. Chlorophyll concentrations as high as these are rarely encountered in the open ocean and possible mechanisms such as seeding from the South Georgia shelf and advection and retention are discussed by Whitehouse et al. (1996). On T2 pigment levels were up to an order of magnitude lower, being only about half of $\mathrm{T} 1$ values in some cases and there was no clear relationship with mean lipid volume. Given the strong response of lipid accumulation to increasing pigment concentrations seen during T1 it seems likely that the decline of the bloom by T2 had adversely affected the ability of the new copepodite stages to feed and store lipid. Drits et al. (1993, 1994) indicated that a similar situation may have existed for Calanus propinquus and Calanoides acutus in the Weddell Sea. Their studies took place between February and April at a time when chlorophyll was decreasing and the populations of $C$. propinquus and C. acutus were preparing to overwinter. Carbon loss via respiration outstripped carbon ingestion at the end of their study period and it was suggested that this shortfall may have been met by mobilization of stored lipid. Great variability in the amount of lipid was seen at this time.

Stored lipid was thought until recently to function as an overwintering metabolic store. However, work has indicated that in some diapausing species overwintering costs may not be great and that a proportion of the lipid is invested in reproduction. (Sargent \& FalkPeterson 1988). Spawning in a number of polar species seems to precede the spring bloom (Fransz 1988, Smith 1990. Hirche \& Kattner 1993, Ward \& Shreeve 1995) and a picture is emerging that during certain phases of a female's reproductive life, lipid can be used to fuel egg production. In this study, however, reproduction is not thought to be implicated as a prime cause of the reduction in lipid volume for 2 reasons. Firstly decreases in lipid were also seen between T1 and T2 for CIVs and CVs. Secondly, on T1 an index of reproduction such as gonad maturity appeared to be proceeding in parallel with increases in lipid volume, both positively related to total pigment levels. On T2 gonad maturity had either stayed broadly the same (Stns 1 and 2), had increased (Stns 3,6,7 and 8) or declined at Stns 9 and 10 where lipid loss was greatest.

Data on lipid class composition for Rhincalanus gigas sampled at the South Georgia shelf and PF stations are broadly in agreement with previous studies. Total lipid content of females (\% dry mass) is relatively low compared to other large Antarctic species such as Calanoides acutus (up to $50 \%$ ) and wax ester is the dominant component (Hagen 1988, Graeve et al. 1994). The 2 - to 3 -fold reduction in dry mass seen at the PF station, the lower lipid content and the absence of egg production perhaps reflects the relatively poor feeding conditions at this station for this species. Calanus simillimus however was somewhat unusual in that TAG was the dominant component, ranging from 55 to $86 \%$ of total lipid content for CVs and adult females at both stations, and wax ester formed a relatively minor contribution. This result is strikingly similar to that seen for the high Antarctic congener Calanus propinquus (Hagen et al. 1993) which, observations suggest, may not undergo diapause and which can be active in surface waters during winter (Nöthig et al. 1991, Hopkins et al, 1993, Schnack-Schiel et al. 1991). Our data can be seen as evidence that $C$. simillimus may occupy a similar niche in the lower latitudes of the ACC and sub-Antarctic. Supporting evidence comes from the bimodality in vertical distribution during winter (Vladimirskaya 1978, Voronina et al. 1978, Atkinson 1991) and from the fact that a proportion of the population (older copepodite stages plus adults) remains in surface waters year round (Atkinson 1991). The ability of this species to produce eggs at the PF station may indicate that it is better adapted to exploit the low food concentrations and smaller size fractions, in particular the protozoan component, that were apparent at this station (Atkinson 1996).

Acknowledgements. We thank officers and crew of RRS 'James Clark Ross' and our colleagues in the BAS Pelagic Ecosystems Studıes programme for assistance at sea. Drs A Atkinson, J. Priddle, A. Clarke and 3 referees made helpful comments on the manuscript. We thank Dr J. Priddle for coordinating the collection of the chlorophyll and pigment data

\section{LITERATURE CITED}

Atkınson A (1989) Distribution of six major copepod species around South Georgia in early summer Polar Biol 9 $353-36.3$

Atkinson A, Ward P, Peck JM, Murray AWA (1990) Mesoscale distribution of zooplankton around South Georgia. Deep Sea Res 37:1213-1227

Atkinson A (1991) Life cycles of Calanoides acutus, Calanus sımillımus and Rhncalanus gıgas (Copepoda: Calanoida) within the Scotia Sea. Mar Biol 109:79-91

Atkinson A (1996) Subantarctic copepods in an oceanıc, low chlorophyll environment: ciliate predation, food selectivity and impact on prey populations. Mar Ecol Prog Ser 130: $85-96$

Baker A de C (1959) The distribution and life history of Euphausia triacantha Holt and Tattersall. 'Discovery' Rep 29:311-339

Bathmann U, Makarov RR. Spirodonov VA, Rohardt G (1993) Winter distribution and overwintering strategies of the Antarctic copepod species Calanoides acutus, Rhincala- 
nus gigas and Calanus propinquus (Crustacea: Calanoida) in the Weddell Sea. Polar Biol 13:333-346

Boysen-Ennen E; Piatkowski U (1988) Meso- and macrozooplankton communities in the Weddell Sea, Antarctica. Polar Biol 9:17-35

Davis RE, Killworth PD, Blundell JR (1996) Comparison of Autonomous Lagrangian Circulation Explorer and fine resolution Antarctic model results in the South Atlantic. J Geophys Res (CI) 101:855-884

Deacon GER (1937) The hydrology of the Southern Ocean. 'Discovery' Rep. 15:3-122

Drits AV, Pasternak AF, Kosobokova KN (1993) Feeding, metabolism and body composition of the Antarctic copepod Calanus propinquus Brady with special reference to its life cycle. Polar Biol 13:13-21

Drits AV, Pasternak AF, Kosobokova KN (1994) Physiological characteristics of the Antarctic copepod Calanoides acutus during late summer in the Weddell Sea. In: Ferrari FD, Bradley BP (eds) Ecology and morphology of copepods. Hydrobiologia 292/293:201-207

Folch J, Lees M, Sloane-Stanley GH (1957) A simple method for the isolation and purification of total lipids from animal tissues. J Biol Chem 226:497-507

FRAM Group (1991) Initial results from a fine-resolution model of the Southern Ocean. EOS Trans Am Geophys Un $72: 174-175$

Fransz HG (1988) Vernal abundance, structure and developement of epipelagic copepod populations of the Eastern Weddell Sea (Antarctica). Polar Biol 9:107-114

Gordon AL, Georgi DT, Taylor HW (1977) Antarctic polar front zone in the western Scotia Sea, Summer 1975. J Phys Oceanogr 7:309-328

Graeve $M$, Hagen W, Kattner G (1994) Herbivorous or omnivorous? On the significance of lipid compositions as trophic markers in Antarctic copepods. Deep Sea Res 41. 915-924

Hagen W (1988) On the significance of lipids in Antarctic zooplankton. Ber Polarforsch 49:1-129 (in German) (Englısh version (1989): Can Transl Fish Aquat Sci 5458:1-149]

Hagen W. Kattner G, Graeve M (1993) Calanoides acutus and Calanus propinquus, Antarctic copepods with different lipid storage modes via wax esters or triacylglycerols. Mar Ecol Prog Ser 97:135-142

Hardy AC, Gunther ER (1935) The plankton of the South Georgia whalıng grounds and adjacent waters. 'Discovery' Rep 11:1-456

Hart TJ (1942) Phytoplankton periodicity in Antarctic surface waters. 'Discovery' Rep 8:1-268

Haury LR, McGowan JA, Wiebe PH (1978) Patterns and processes in the time-scales of plankton distributions. In: Steele JH (ed) Spatial pattern in plankton communities. Plenum Press, New York, p 277-327

Hirche HJ, Kattner G (1993) Egg production and lipid content of starved and fed Calanus glacialıs: indication of fooddependent and food independent reproductive mode. Mar Biol 117:615-622

Hofmann EE, Whitworth $T$ (1985) A synoptic description of the flow at Drake Passage from year-long measurements. J Geophys Res 90:7177-7187

Hopkins TL, Lancraft TM, Torres JJ, Donelly J (1993) Community structure and trophic ecology of zooplankton in the Scotia Sea Marginal lce Zone in winter (1988). Deep Sea Res 40:81-105

Huntley M, Brinton E (1991) Mesoscale variation in growth and early development of Euphausia superba Dana in the western Bransfield Strait region. Deep Sea Res 38 : $1213-1240$
Huntley M, Escritor F (1991) Dynamics of Calanoides acutus (Copepoda: Calanoida) in Antarctic coastal waters. Deep Sea Res 38:1145-1167

Kanaeva IP (1968) Distribution of mass copepods in the western part of the Scotia Sea. Oceanology 8:562-569

Legeckis R (1977) Oceanic polar front in Drake Passagesatellute observations during 1976. Deep Sea Res 24: 701-704

Mackintosh NA (1934) Distrıbution of macrozooplankton in the Atlantic sector of the Antarctic. 'Discovery' Rep 9: $65-160$

Mackintosh NA (1937) The seasonal circulation of the Antarctic macroplankton. 'Discovery' Rep 16:365-412

Marin V (1987) The oceanographic structure of the eastern Scotia Sea-IV. Distribution of copepod species in relation to hydrography in 1981. Deep Sea Res 34:105-121

Nöthig EM, Bathmann U, Jennings JC Jr, Fahrbach E, Gradinger R, Gordon LI, Makorov R (1991) Regional relationships between biological and hydrological properties in the Weddell Gyre in late austral winter 1989. Mar Chem $35: 325-336$

Nowlin WD, Klinck J (1986) The physics of the Antarctic Circumpolar Current. Rev Geophys 24:468-491

Olsen RE, Henderson RJ (1989) The rapid analysis of neutral and polar marine lipıds using double-development HPTLC and scanning densitometry. J Exp Mar Biol Ecol 129:189-197

Ommanney FD (1936) Rhincalanus gigas (Brady) a copepod of the southern macroplankton. 'Discovery' Rep 13:231-334

Platkowski U (1989) Macroplankton communities in Antarctic surface waters: spatial changes in relation to hydrography. Mar Ecol Prog Ser 55:251-259

Priddle J, Croxall JP, Everson 1, Heywood RB, Murphy EJ, Prince PA, Sear CB (1988). Large scale fluctuations in distribution and abundance of krill-a discussion of possible causes. In: Sahrhage D (ed) Antarctic ocean and resources variability. Springer-Verlag, Berlin, p 169-182

Sargent JR, Falk-Peterson S (1988) The lipid biochemistry of calanoid copepods. In: Boxshall GA, Schminke HK (eds). Biology of copepods. Hydrobiologia 167/168 p 101-114

Schnack-Schiel SB, Hagen W, Mizdalski E (1991) Seasonal comparison of Calanoides acutus and Calanus propinquus (Copepoda:Calanoida) in the southeastern Weddell Sea, Antarctica. Mar Ecol. Prog Ser 70:17-27

Smith SL (1990) Egg production and feeding by copepods prior to the spring bloom of phytoplankton in Fram Strait, Greenland Sea. Mar Biol 106:59-69

Tarling GA, Ward P, Sheader M, Williams JA, Symon C (1995) Distribution patterns of macrozooplankton assemblages in the south-west Atlantıc. Mar Ecol Prog Ser 120:29-40

Tréguer P, Jacques G (1992) Dynamics of nutrients and phytoplankton, and fluxes of carbon, nutrogen and silicon in the Antarctic Ocean. Polar Brol 12:149-162

Vervoort W (1965) Notes on the biogeography and ecology of free-living marine copepoda. In: Oye P van, Mieghem J van (eds) Biogeography and ecology in Antarctica. Junk. The Hague, p 381-401

Vidal J (1980) Physioecology of zooplankton. 1. Effects of phytoplankton concentration, temperature and body size on the growth rate of Calanus pacificus and Pseudocalanus sp. Mar Biol 56:111-134

Vladimirskaya YeV (1978) Age composition of winter populations of abundant copepod species in the southern part of the Scotia Sea. Oceanology Wash 18:202-204

Voronina NM (1970) Seasonal cycles of some common Antarctic copepod species. In: Holdgate MW (ed) Antarctic ecology Academic Press, New York, p 162-172 
Voronina NM (1978) Variability of ecosystems. In: Charnock $H$, Deacon $G$ (eds) Advances in oceanography. Plenum Press, New York, p 221-243

Voronina NM, Vladimirskaya YeV, Zmijevskaya MI (1978) Seasonal variations in the age composition and vertical distribution of common zooplankton species in the Southern Ocean. Oceanology Wash 18:335-338

Ward P, Shreeve RS (1995) Egg production in three species of Antarctic calanoid copepods during an austral summer Deep Sea Res 42:721-735

Ward P, Shreeve RS, Cripps GC (in press) Rhincalanus gigas

This article was submitted to the editor and Calanus simillimus: lipid storage patterns of two species of copepod in the seasonally ice free zone of the Southern Ocean. J Plankton Res

Whitehouse MJ, Priddle J, Trathan PN, Brandon MA (1996) Substantial open-ocean phytoplankton blooms to the north of South Georgia, South Atlantic, during summer 1994. Mar Ecol Prog Ser 140:187-197

Whitworth T III, Nowlin WD, Pillsbury RF, Moore MI, Welss RF (1991) Observations of the Antarctic circumpolar current and deep boundary current in the South west Atlantic. J Geophys Res (C8) 96:15105-15118

Manuscript first received: October 30, 1995

Revised version accoptcd: May 15, 1996 